\title{
Inheriting Inherit the Wind: Debating the Play as a Teaching Tool
}

\author{
Edward J. Larson • David Depew • Ronald Isetti
}

Published online: 15 February 2008

(C) Springer Science + Business Media, LLC 2008

Keywords Inherit the Wind . Scopes trial

\section{Teaching Inherit the Wind: An Introduction}

Edward J. Larson

Professor of Law and History

Pepperdine University and University of Georgia

The 1960 film Inherit the Wind (ITW) speaks to so many of the tensions intrinsic to mid-twentieth century American life that, with superb acting, scripting, and stage direction, it quickly became a film classic. Based on a 1955 play that had set records as the longest running drama on Broadway, the movie featured renowned actors Spencer Tracy, Fredric March, and Gene Kelly. Its opening scene sets the tone. A delegation of small-town officials led by a stern-faced minister interrupts a likeable young high school science teacher in the midst of telling his students about the Darwinian theory of human evolution. His teaching violates the law, the teacher is told, and he is placed under arrest in full view of his wide-mouthed students. In the background,

D. Depew $(\bowtie)$

Communication Studies, University of Iowa,

BCSB 105,

Iowa City, IA 52242, USA

e-mail: david-depew@uiowa.edu

E. J. Larson

Department of History, University of Georgia,

334 LaConte Hall,

Athens, GA 30602, USA

R. Isetti

c/o Department of History, St. Mary's College of California,

P.O. Box 4300 ,

Moraga, CA 94575, USA the voice of the great African-America soloist, a thenyouthful Leslie Uggams, softly sings "Give Me That Old Time Religion." Cut to a stack of big-city newspapers reporting the story in shocked headlines, then back to the small, vaguely southern town, where the jailed teacher becomes a social outcast.

Teaching Darwinism undermines the faith of students in the biblical account of human creation, townspeople are told by the scowling minister. His very name, Jeremiah Brown, evokes images of the fanaticism of the biblical Jeremiah and the abolitionist John Brown. His actions reinforce these images. "Do we curse the man who denies the Word?" Brown rhetorically asks the assembled townspeople at one point in the play. "Yes," they reply in unison. "Do we cast out this sinner in our midst?" he adds, prompting a mightier affirmation from the crowd. "Do we call down hellfire on the man who has sinned against the word?" Brown shouts. The mob roars its assent.

Although the teacher is named Bert Cates and the town called Hillsboro, viewers surely equate him with John Scopes and transpose the scene onto the historic events that transpired in Dayton, TN, during the summer of 1925. In $I T W$, the main characters (except Brown and Scopes's fiancé, who had no parallels in Dayton) are given soundalike pseudonyms for their real names. The script sets the time simply as "summer, not too long ago" and the place as "a small town." Stage directions for the play begin, "It is important to the concept of the play that the town is always visible, looming there, as much on trial as the individual defendant." Although the movie version begins with the dramatic schoolroom arrest, the play is limited to fewer sets. It opens with a jailed Scopes explaining why he had been arrested. "You know why I did it," he says. "I had the book in my hand, Hunter's Civic Biology. I opened it up, and read to my sophomore science class Chapter 17, 
Darwin's Origin of Species." For innocently teaching his students, the script notes, Scopes "is threatened with fine and imprisonment." The movie and play suggest various basic tensions that animate modern American life: science vs. religion, small town vs. big city, North vs. South, tradition vs. progress, law vs. conscience, the mob vs. the individual, popular control over public education vs. academic freedom for teachers and students, biblical literalism vs. religious liberalism, and tolerance vs. conformity. Many of these issues resonate with teenagers, especially when presented in the context of what is taught in high school. Accordingly, ITW has become a staple for high school drama productions in addition to its widespread use in history classes.

Any literary or artistic work as popular as this play and movie acquires a life of its own. Its various viewers bring meaning to it, and if, like $I T W$, it remains well-liked over several generations, each generation of viewers typically brings it new meaning. The same is true with history. Chronicled historical events not only draw meaning from their context but also gain meaning from being chronicled. The account of a particular historical event reveals something about the time when it took place, something about the time when it was recorded, and something about the time it is read. As a work of historical fiction that is still widely used in schools, ITW is a window into the 1920s, when the Scopes Trial occurred; into the early 1950s, when Jerome Lawrence and Robert E. Lee wrote the play in response to the McCarthy Era persecution of alleged communists; into the later 1950s, when blacklisted screenwriters took that play and made it into a movie to be released on the eve of the 1960 presidential election; and today, when it is adopted for classroom use. It raises themes relevant to each of these periods and has been used effectively by teachers to instruct students about all of them.

Doing so is controversial, however, because neither the play nor the movie is exclusively about any one of these periods. Indeed, when discussing their work, the play's writers stressed that "Inherit the Wind does not pretend to be journalism. It is theatre. It is not 1925." The play's preface notes, "It might have been yesterday. It could be tomorrow." The movie's set looks as much like a small town in the 1950s as one in the 1920s. No telltale indicators of either decade appear, such as period automobiles. If the presentation is not set in one particular period, some critics ask, how can history teachers use it to instruct students about the 1920s, the 1950s, or any other distinct time? Of course, these concerns about using historical fiction to teach history are not unique to ITW. Similar ones are raised about using either Shane or The Virginian to teach about Wyoming's so-called Johnson County War, for example, or Grapes of Wrath to present life in the Dust Bowl during the Depression. These novels and movies can be powerful teaching tools, but they will inevitably raise objections from some who say the accounts are biased or inaccurate.

In the following articles, two college teachers, Communications Studies Professor David Depew and History Professor Ronald Isetti, debate the merits of using $I T W$ in the classroom. They discuss whether it is mainly about the 1920s or mainly about the 1950s and whether it is accurate enough in its portrayal of its principal historical charactersthe progressive politician and lay religious leader William Jennings Bryan and the great defense attorney and public skeptic Clarence Darrow-to do them justice in light of history. Of course, ITW remains popular largely because it addresses matters that Americans care deeply about today, such as the continuing controversy over teaching evolution in public schools and the virtue of tolerance. The essays discuss these matters as well and credit ITW for raising them in a manner accessible to students. Ultimately, both authors find ITW to be a valuable teaching tool, as do I, but they differ on how it should be employed. Their debate, drawing as it does on long classroom experience, can help teachers make better use of this popular classroom resource. That is my hope in offering it to you along with a list of references and suggested readings composed by the authors.

\section{Inherit the Wind Versus the Scopes Trial}

\section{David Depew \\ Communication Studies, Project on the Rhetoric of Inquiry The University of Iowa}

To demand that a novel, play, or film that refers to historical events conform strictly to the facts is to misunderstand art. It is even more churlish to complain that something has been left out. Nonetheless, if you use $I T W$ to teach history, government, religion, biology, or even literature, I think you should compare the trial as portrayed in the play and the 1960 film based on it with the real thing, perhaps asking your students to do some research and report back. The gap between the fictional account and its original, that is to say, might be a good topic for classroom inquiry. The play or the film can be a useful and accurate pedagogical tool, but I think good teaching and learning will happen only if ITW comes with a few "liner notes," some of which I now offer.

The Preface to the play asks audiences to experience the plot not as history but as a cautionary fable in which ignorance and superstition are morally, if not legally, bested by the spirit of free inquiry and free expression. Did the authors seriously think that the audience would not recognize this as the Scopes trial? Of course not. In the 
Preface they acknowledge that "the events that took place in Dayton, Tennessee...in 1925 are clearly the genesis of the play." In spite of the fact that Lawrence and Lee go on to disclaim any intent to be accurate or historical at all, however, audiences - even those who read the Preface-do regularly take $I T W$ to be about the Scopes trial. In fact, the play and the 1960 film (which has no preface) have fixed most people's image of that event as firmly as Dickens's $A$ Tale of Two Cities has forever fixed our highly inaccurate image of the French Revolution. If you show the film or have students read the play in a biology or history class, where facts are the currency, this impression is likely to be intensified. Hillsboro is Dayton. Matthew Brady is William Jennings Bryan. Henry Drummond is Clarence Darrow. Hornbeck is the famous reporter H. L. Mencken.

Why, then, did Lawrence and Lee instruct the audience not to do what the play encourages them to do? The answer, I think, is that, by recasting history as myth, they were encouraging their audience to blur Scopes with Galileo and the Salem witches, whose trials Arthur Miller had used as a vehicle for attacking McCarthyism in his 1953 play The Crucible and, more recently, with Sacco and Vanzetti, whose fates as American leftists had been dramatized in Maxwell Anderson's Winterset, which served Lawrence and Lee as a model (Lawrence and Lee 1953; Larson 1997, 240). The Preface warns that what took place in Dayton "not too long ago...could happen tomorrow." People who attend the contemporary Broadway revival of ITW will undoubtedly see Lawrence and Lee as presciently predicting the rise of the latter-day religious right's reiterated crusade to blunt the teaching of evolution. However, they were doing no such thing. They had McCarthy's assault on first amendment freedoms on the brain.

Hillsboro-Dayton The stage directions portray Hillsboro as a "sleepy obscure country town about to be awakened." That helps set a mythic mood. However, Dayton was no such place. It was a new, if small, commercial center whose leading citizens provoked the trial to create a profitable media circus (Larson 1997). Nor was its religious sensibility that of Hillsboro's Reverend Jeremiah Brown, whose speeches are indeed "Jeremiads" and whose obsession with fiery damnation sounds like Cotton Mather. Truth be told, Dayton was in the throes of a very new-fangled version of the old time religion. In contravention of the traditional Protestant call to interpret Scripture for oneself, the Fundamentalist movement, which had been instigated as recently as 1910, demanded literalism to push back socalled "modernist" or "liberal" forms of biblical interpretation, which it took to be corrupting the mainline churches. Evolution got into the act because it required a nonliteral interpretation of Genesis. A good deal of the North-South tension alluded to in the play was about this issue. In the early twentieth century, American Protestantism, the deepest stratum of our cultural life, was breaking into two camps, creating a white-white cultural and political divide that persists to this day. The Liberal Protestant churches of the North were liberal because they had a liberal, or interpretively free, approach to Scripture, not because they were full of liberals as we now understand the term. That allowed them to think that evolution and Genesis are compatible. Fundamentalists denied this. They thought liberalism about Scriptures would lead to liberalism about morality. Their contemporary avatars think that is just what happened.

Scopes-Cates The play vaguely casts the issue in the trial as freedom of inquiry and speech. It has Bert Cates suffer imprisonment for using his mind. But Scopes was never put in jail, and the fledgling American Civil Liberties Union (ACLU) did not challenge the right of school boards, local communities, or states to compel teachers to stick to the approved curriculum, as they still do not. In fact, teaching the approved curriculum is exactly what Scopes did. He got the text from which he taught, Hunter's Civic Biology-a eugenicist tract urging students to watch carefully who they kiss or marry; that is the "civic" part-from the approved textbook depository. The trial was about the first amendment, all right, but it was not about freedom of inquiry or speech. It was about the establishment clause, which forbids states and the federal government to favor any particular religion or sect. The ACLU's argument was that Tennessee was violating this clause by sanctioning one, and only one, interpretation of the Bible. The defense also argued that you could not responsibly teach biology, as the state constitution required, unless you at least mentioned evolution.

Malone-Nobody This case was argued most fully by the natty divorced Catholic lawyer Dudley Field Malone, who has no counterpart in ITW. In his summation, Malone said that the Bible should be kept "in the world of your individual judgment, in the world of the Protestant conscience that I heard so much about when I was a boy." He also said that nothing about evolution logically precluded religious belief. Therefore, Scopes could not possibly have violated the law against teaching anything inconsistent with the Bible. The speech was greeted with such enthusiastic applause that, according to Mencken, Darrow turned to him and said, "Good God! That scoundrel will hang the jury" (Mencken 1943, 236-7). An acquittal would have defeated the defense's purpose, which was to get Scopes convicted, but in a way that would lay the groundwork for a law-testing appeal. This strategy was upended when Judge Raulston ruled out the oral testimony of all but one of defense's expert witnesses, seven 
biologists and geologists who saw no inherent contradiction between evolution and the means by which God went about the work of creation (the judge did allow their statements to be included in the transcript). In doing so, Raulston was upholding the prosecution's contention that all this stuff was irrelevant to the narrow issue of whether Scopes had actually violated the law. ITW preserves this moment, but lacking its legal context, ascribes the judge's reason for refusing to hear the witnesses to an Orwellian Catch-22, according to which the law against teaching evolution itself precluded letting witnesses who denied the logical inconsistency of evolution and the Bible on the stand. More bigoted and perverse constraints on freedom of speech.

Bryan-Brady That seemed to end the matter, with the crestfallen Mencken regretting that the anticipated DarrowBryan confrontation he had been touting to his readers like a prize fight would not take place. Then, the defense decided to make its point by picking up the other end of the stick: expertise on the meaning of the Bible. Cunningly, Darrow goaded Bryan into testifying as an expert on this subject. Big mistake. Darrow cleverly squeezed Bryan between literalist fundamentalism and his own quasimodernist interpretation of Genesis, according to which, biblical days could mean entire geological eras. The admission was stunning not because Bryan confounded the local yokels, but because he was supporting the defense's main contention!

This moment is badly misrepresented in ITW and the film. Brady shows his fundamentalist credentials by asserting Bishop Usher's chronology. "The Lord began the Creation on the 23rd of October in the Year 4004 B.C. at 9:00 A.M.," he says. Asked by Drummond whether the 7 days each had 24 hours, Brady says he does not know. "What do you think?" asks Drummond. "I don't think about things like that," says Brady. He does not think. He does not inquire. He does not use his mind.

In fact, however, even at the end of his life, Bryan was not the vainglorious, close-minded glutton that ITW kicks around. If anything, he thought too much with too little equipment for doing so. Like all Populists and Progressives, including Darrow and Mencken, Bryan had opposed the dog-eat-dog Social Darwinism that at the turn of the century served capitalists as a convenient ideology. In the years leading to Dayton, Bryan became even more incensed by the eugenics movement, which he saw, not entirely unreasonably, as the latest incarnation of Darwinism. He also knew that eugenics was being pawned off by selfstyled Progressive elites onto high school teachers in texts like Hunter's Civic Biology. Reasons for thinking that a truly scientific Darwinism not corrupted by either Social Darwinism or eugenics still lay in the future. However, Bryan was long gone by the time the Modern Evolutionary
Synthesis arrived on the scene. Therefore, for him, the only way back toward community-based populist self-government was to oppose Darwinism in all its forms and to move ever more logically, fatally, and tragically toward biblical literalism.

Darrow-Drummund Drummond is an uncomplicated liberal who defends free inquiry in every possible venue. One can readily see him sticking up for Joyce's Ulysses or Lawrence's Lady Chatterly's Lover. He walks off the stage with both the Bible and Origin of Species in his briefcase. Harking back to Voltaire, he defends Brady's right to be wrong against the cynicism of Hornbeck, who in turn reproaches him for being an atheist who believes in God. However, Clarence Darrow was nothing like this. He opposed what he called "the eugenics cult" not for Bryan's reasons, but because he was an environmental, not a genetic, determinist. He was in the tradition of naturalistic, muckraking novelists like Theodore Dreiser and Frank Norris. Darrow did not think that the teenage murderers Leopold and Loeb, whom he had just successfully saved from the death penalty, were victims of their ancestors' bad seed, but of their own background and their unfortunate habit of reading Nietzsche and Dostoyevsky. In developing his arguments against capital punishment, which was his stock in trade, Darrow pinned his hopes on empowering a class of social scientific experts. What enraged him about his former political ally Bryan, and provoked him to show him up, was that, in his view, Bryan had led the American left into a right-wing, know-nothing dead end.

Mencken and Hornbeck Lawrence and Lee put into Hornbeck's mouth Darrow's self-exculpating remark that Bryan had "died of a busted belly." This change from the historical record allows Drummond to be the hero of free speech and inquiry that the play wants him to be. He reproaches Hornbeck for talking in this disrespectful way because, he says, Brady had once been a great man. He spoke his mind. He exercised his right to be wrong. Darrow made the remark, however, not only because he was unrepentant, but because he was a materialist, whose environmental determinism resisted all ideal or spiritual explanations. In his view, Bryan really did die of a busted belly. Nor, for that matter, was Mencken a cynical, materialistic bystander like Hornbeck. He was a passionate skeptic who opposed in equal measure both sides of the growing schism in American Protestantism and, relatedly, the Democratic party. He rallied against the ungrounded scientism of the Progressive elites, especially eugenics, as well as the superstitious tribalism of what he was the first to call "the Bible belt."

In his best-selling, Pulitzer prize-winning account of the Scopes trial, Summer for the Gods, Edward Larson shows that, in framing their play, Lawrence and Lee passed on 
"the Scopes legend" that has remained constant ever since Frederick Lewis Allen's (1931) description of the trial in his journalistic portrait of the 1920s, Only Yesterday (Larson 1997, 245). The "not too long ago" of Lawrence and Lee's Preface echoes Allen's title as well as his mythic sense of time. Allen redescribes the trial as a titanic conflict between the freedom of inquiry on which science depends and religious belief generally, not just fundamentalism. Noticing that this is not exactly how the trial was framed or received at the time, Allen writes, "The issue of the Scopes trial as the great mass of newspaper readers saw it was nothing so abstruse as the rights of taxpayers versus academic freedom. In the eyes of the public the trial was a battle between fundamentalism and twentieth century skepticism (assisted by modernism)" (Allen 1931, 202). However, nothing as abstruse as academic freedom was, in fact, at issue in the Scopes trial. Fundamentalism versus modernism is not only what readers thought the trial was about. That is what it was about. It is no doubt true that the expansion and protection of personal rights and freedoms that defines the political liberalism despised by contemporary fundamentalists was already a gleam in the eye of the ACLU. It is also true that the rudiments of this tolerant philosophy were soon to be incubated by the New Deal (partly as a way of easing tensions between the Northern and Southern halves of the Democratic Party). However, these themes, which stand out in ITW, are barely visible in the transcript of the Scopes trial. ${ }^{1}$

By using $I T W$ as a stimulus for research, reports, and classroom debates, I think students can learn to engage in responsible citizenly discussions about how science, religion, and society are properly related in and through our contentious democratic forms of public discourse. I cannot imagine, however, that such exercises will bear much fruit if they do not focus on the gap between the actual trial and $I T W$ in its several context-dependent incarnations. Students

\footnotetext{
${ }^{1}$ In this paper, I depart slightly from Edward Larson's account. Larson rightly reproaches Allen for his exaggerated characterization of the conflict as a struggle between religion generally and freedom of inquiry (Larson 1997, 226). In the passage I have quoted, Allen climbs up to this height by eliding the difference between skepticism and modernism. Larson is right to say that this leaves no room for the defense's actual position, namely, that one can be a religious evolutionist, that is, in the relevant sense of the term, a "modernist." However, Larson continues to accept the other half of "the Scopes myth," namely that the ACLU was defending individual rights rather than a version of the "liberal," "modernist" side in the conflict about biblical interpretation raging within American Protestantism. It is modernism that grounds the right of scientists, the only free inquirers who count in this context, to determine school science curricula. Bert Cates could no more tell his students about the results of his and Rachel's personal free inquiry than John Scopes could. This is the sort of issue that can arise from more than casual discussions of ITW.
}

cannot get started or go very far in this direction without some background and some guidance. Therefore, I hope my effort to follow Edward Larson's lead in identifying some of the relevant topics and issues proves helpful.

\section{Inherit the Wind and the Conflict Between Urban and Rural America in the 1920s}

\section{Ronald Isetti \\ Department of History Emeritus \\ St. Mary's College of California}

Strictly speaking, the Broadway play ITW, based on the notorious Scopes trial of 1925, has little to do with Darwinism as such. This was precluded by the judge's decision, both in the trial and in the play, to exclude from the court's testimony most of the scientific evidence supporting evolution. The motions of defense attorney Henry Drummond (Clarence Darrow in real life) to place zoologists, geologists, archeologists, and even friendly theologians on the stand were summarily denied. The only legal point at issue was whether or not Bertram Cates (John Thomas Scopes) used Hunter's Civic Biology to teach Darwinism to his students, and, on this question, all sides were in complete agreement. He had. As a result, it seemed as if this titanic trial would become a big bust. It was then that the defense team (probably Arthur Garfield Hays rather than Darrow, as the play suggests) came up with the bright idea of putting William Jennings Bryan (Matthew Harrison Brady in the play) on the stand to defend a literal interpretation of the Bible. In an instant, the prosecuting attorney became the chief defendant, and the Bible was put to the test rather than The Origin of the Species. This begs the question of who really was on trial. In the play, the accused Bertram Cates (John Thomas Scopes) is a minor character who never testifies either on his own behalf or for Darwin, although, at one point, he tells his fictional girlfriend, Rachel, that The Origin of the Species rightly says "that man was not just stuck here like a geranium in a flower pot; that living comes from a long miracle, it just didn't happen in seven days." A rather folksy, homespun, and even faintly Biblical description of natural selection! But it is not much to go on.

In my experience, the very absence of biology in ITW shows why the play provides a better springboard for class discussion of the fundamentalist interpretation of the Bible than for the persuasiveness of Darwin's theory of evolution, although Drummond attempts to insinuate Darwinism into his cross examinations and his court comments ("Darwin," the Darrow character Henry Drummond tells the jury, "moved us forward to a hilltop, where we could look back and see the way from which we came. But for this view, this insight, we must abandon our faith in the pleasant 
poetry of Genesis"). Accordingly, I will try to show that $I T W$ effectively raises questions about fundamentalism, the control of education, free thought, and the impact of technology that are still important and can lead to lively, informative class discussions, especially if the students' responses are not weighted down by commentary, warnings, or what my longtime friend David Depew calls "liner notes." To make this point, I will argue that the play is firmly anchored in the social, political, and religious milieu of the 1920s rather than in that of the McCarthy era. Its evocation of that era is vivid and accurate enough on its own to stimulate discussions that will resonate today.

In his role as prosecutor and on the stand as a witness, the play's Matthew Harrison Brady makes a complete fool of himself, playing to the crowds, making long-winded speeches, betraying the trust of his chief witness, flaunting his gross ignorance of Darwinism ("never read it"), identifying sex with original sin, and getting caught in logical traps time and again by the relentless Drummond. $\mathrm{He}$ is finally forced to admit that a "day" in Genesis could be construed as much longer than a 24-hour period, completely undercutting the literal interpretation of the Scriptures on which his inveterate opposition to "evilution" is largely based. Bleeding profusely from Drummond's razor sharp cuts, Brady is reduced in the play to a blithering hasbeen, who toward the end of the court proceedings attempts to deliver the inaugural address he had never been able to make (Brady's real life counterpart, William Jennings Bryan, had been nominated for the presidency no less than three times by his fellow Democrats, but was never elected).

Brady is exposed by the playwrights Jerome Lawrence and Robert E. Lee as the enemy of free inquiry, academic freedom, and common decency. Nonetheless, I am not convinced that they were writing mainly from the perspective of the red scare of the 1950s when such conventions were being attacked and when the play was written and produced, but rather in terms of a commonly used, but largely accurate historical lens for viewing the Scopes trial, that is to say, the cultural conflict between urban and rural America that emerged in the 1920s and was also clearly evident in the fight over prohibition and immigration restriction, the rise of nativism, the opposition to the revival of the Ku Klux Klan, and the landmark election of 1928. This thesis was first advanced by the journalist Frederick Lewis Allen in Only Yesterday: An Informal History of the Nineteen-Twenties in America, but its most convincing and literate articulation may be found in Leuchtenburg's 1955 justly acclaimed and widely read paragraph on the 1920s, The Perils of Prosperity, 1914-1932. Although Lawrence and Lee may not have painted a fully accurate picture of the Scopes trial itself, they most certainly did their homework from an historical point of view; the cultural context in which they place their work is authentic and richly detailed and, in my judgment, has little to do with the 1950s. Alluding to the pervasive nativism of the 1920 s, when Congress effectively cut off further immigration from Eastern and Southern Europe, the playwrights have Brady respond to the notion that human beings evolved from Old World monkeys with this sarcastic taunt: "Did you hear that friends? 'Old World Monkeys'! According to Mr. Cates, you and I aren't even descended from good American monkeys!" Furthermore, of course one of the few legal drinks available in Heavenly Hillsboro is the lemonade being hawked by enterprising vendors outside the crowded courthouse.

In ITW, more than Brady and his literal interpretation of the Bible are on trial. Lawrence and Lee twice tell us in the stage directions that the town itself (standing in for the historical Dayton, TN, and for all southern small towns) is "as much on trial as the individual defendant" (this makes it more relevant to ask students, in discussing the play, "what" rather than "who" is on trial). This "sleepy, obscure country town" is about to be assaulted, to use the words of Matthew Harrison Brady, by "a wicked attack from the big cities of the North." Both city slickers, dressed in "the latest fashion" of jazz-drenched Chicago and Sodom-like Baltimore, Henry Drummond and E. K. Hornbeck, the caustic metropolitan reporter who is really H. L. Mencken, represent and personify all that small-town, Protestant, rural America fears and despises - agnosticism, scandal-mongering newspapers, loose sexual morality, immigrants, liberal universities, Freudianism, bootleg gin, speakeasies, free thought, and scientific doubt. As the play proceeds, Heavenly Hillsboro, put under the microscope by the modern, secular America that was emerging in the 1920s, is convicted of ignorance, intolerance, gross materialism, hypocrisy, bigotry, nativism, prohibition, sexual repression, and the suppression of free thought and inquiry. What is at stake in the play is the seismic cultural conflict between modern and traditional America or between scientific and fundamentalist America in the jazz age, a conflict that seems today as intense and widespread as ever. And this is precisely why ITW recently played to packed audiences on Broadway.

For the authors of the play, speaking through the character of Hornbeck, the clear losers, in the context of the drama, are Brady and the small town America of which he is the chief mouthpiece. Turning to Rachel Brown, the Reverend Brown's daughter and Bertram Cates' girlfriend, Hornbeck admonishes her:

Wake up, Sleeping Beauty. Time was when Brady was hero of the hinterland. Water-boy for the great unwashed. But they've got inside plumbing in their heads these days. There's a highway through the backwoods now. And the trees of the forest have reluctantly made room for their leafless cousins, the telephone poles. Henry's Lizzie rattles into town and 
leaves behind the Yesterday-Messiah standing in the road in a cloud of flivver dust. The boob has been deboobed. Colonel Brady's virginal small towner has been had-by Marconi and Montgomery Ward.

This remarkable monologue alludes to many significant developments that took place in the 1920s - the spread of radio (KDKA in Pittsburgh went on the air at the beginning of the decade), the widespread purchase of home appliances, the increasing use of telephones, the development of the car culture (exemplified by Ford's famous Model T), and the proliferation of chain stores (Owl Drugstores and Monkey Wards, as my mother used to say), among other things.

But although Lawrence and Lee were "spot-on" in recreating the flavor of the roaring 1920s, they were blatantly wrong in their overly optimistic judgment about the power of science and technology to change the public's thinking about the Bible and evolution, then and now. Today, we have flat-screen HD television sets, i-Pods, cell phones, computers, faxes, and a myriad of other electronic devices and marvels, wireless connections rather than telephone lines, interstate highways and jet transportation, super Wal-Marts rather than Montgomery Wards, and many other examples of the triumphs and marvels of modern technology and merchandising, not to mention universal schooling and near universal literacy. However, the number of fundamentalists and the percentage of those who reject evolution and believe in the literal interpretation of Genesis seem to have expanded rather than contracted since the days of the Scopes trial. Three Republican candidates for their party's presidential nomination have publicly stated that they do not accept evolution. Many Americans seem more close minded and less open to the dictates of reason than ever, spawning in reaction a cottage industry of militant atheists and evolutionary biologists such as Harris, Dawkins, and Hitchens, who decry religious faith and organized religion and plead for the return of reason and sanity.

Most critics (and students in class discussions) argue that Drummond is the hero of the play. They admire him for his respect for reason and the sanctity of the human mind, his incisive questioning of the "poetry" of the Bible, his defense of free thought, his respect for Brady and his beliefs, however wrong they may be, and his symbolic attempt at the end of the play to bring science and religion together in piling Darwin on top of the Bible as he leaves the court room. However, for others, especially women students, the real hero of the play is Rachel. At the beginning of the drama, she urges Cates to give up his fight, obey the law, and respect the right of the local school board to determine what is taught in the classroom (here is another good discussion topic-Who decides what should be taught in high school classrooms?). By the end of the play, however, she has begun to change her mind. In effect, she has started to think for herself-which is what Drummond (and by extension Lawrence and Lee) want us all to do. At one point in the trial, Drummond cries out that what is really on trial in Heavenly Hillsboro is the "right to think." At the end of the play, Rachel tells Cates that she does not understand Darwin or want to think that men came from apes and monkeys, but then quickly adds "that's beside the point." Then, turning to Drummond, she says in what may be the key passage of the entire play:

I hope I haven't said anything to offend you. I haven't really thought very much, I was almost afraid of what I might think-so it seemed safe not to think at all. A thought is like a child inside our body. It has to be born. If it dies inside, you die, too! The ideas have to come outlike children. Some of 'em healthy as a bean plant, some sickly. I think the sickly ideas die mostly.

The problem is in fact to get the American public to think, which is no small task - and ITW can help.

I am not convinced that fundamentalist Christians today oppose evolution mainly because they fear that it will undermine traditional morality, as Bryan apparently did. Materialism, the Internet, modern media, and TV preachers themselves have already done a good job of doing that, especially in the red states (more religious) whose statistics on divorce, teenage pregnancy, and other such "moral" indicators are significantly worse than those of blue states (less religious). Fundamentalists reject evolution because it conflicts with the Bible, especially with the account of creation found in Genesis. They stake everything on the literal truth of this book, as if their whole mental universe would collapse if it were proved to be incorrect. As proponents of the "young earth" movement, they adamantly assert, as Brady did in the trial and in the play, that our planet was created about 4,000 years ago and, further, that dinosaurs and human beings lived happily together in the not too distant past. How anyone can make such claims today in the face of the discoveries of modern physics, chemistry, geology, paleontology, and evolutionary biology boggles the mind.

It all goes back to the false and dangerous notion, affirmed by Brady under cross-examination, that the Bible was dictated directly by God and contains all Truth, even as to the way the universe was created. Drummond comes much closer to the truth when he blurts out in the courtroom, "The Bible is a book. A good book. But it's not the only book." There are other inspired books (I hesitate to add the adverb divinely), and one of them surely is Darwin's The Origin of the Species.

I support using $I T W$ in the classroom and letting it speak for itself. It gets students to think about important issues, even if Darwinism as such is not among them. 


\section{References and Suggested Reading}

Allen FL. Only yesterday: an informal history of the nineteen-twenties in America. New York: Harper and Row; 1931.

Larson E. Summer for the Gods: the scopes trial and America's continuing debate over science and religion. New York: Basic Books; 1997.

Lawrence J, Lee RE. The genesis and exodus of the play. Theatre Arts, August 1953.

Leuchtenburg W. The perils of prosperity, 1914-1932. Chicago: University of Chicago Press; 1955.

Mencken HL. Heathen days. New York: Knopf; 1943.

\section{Further Reading}

No author. The world's most famous court trial: State of Tennessee v. John Thomas scopes. New York: Da Capo Press; 1971. A complete transcript of the trial.
Bryan WJ. In his image. New York: Revell; 1922.

Darrow C. The essential words and writings of Clarence Darrow. New York: Modern Library; 2007 (a representative collection of Darrow's published writings, public addresses, and courtroom arguments).

Ginger R. Six days or forever? Tennessee v. John Thomas scopes. Chicago: Quadrangle Paperbacks; 1958.

Jasanoff S. Designs on nature: Science and democracy in Europe and the United States. Princeton: Princeton University Press; 2005.

Hunter G. A civic biology. New York: American Book Co; 1914.

Kazin M. A Godly hero: the life of William Jennings Bryan, New York: Alfred A. Knopf; 2006.

Lawrence J, Lee RE. Inherit the wind. New York: Ballantine Books; 1960.

Levine L. Defender of the faith: the last decade, 1915-1925. New York: Oxford University Press; 1965.

Lippmann W. American inquisitors: a commentary on Dayton and Chicago. New York: Macmillan; 1928.

Sprague de Camp L. The great monkey trial. New York: Doubleday; 1968.

Tierney K. Darrow: a biography. New York: Crowell; 1979. 